\title{
ANTIOXIDANT ACTIVITY AND ISOLATION BIOACTIVE COMPOUNDS FROM ROSELLE (HIBISCUS SABDARIFFA) FROM VARIOUS METHODS AND DRYING TIME
}

\author{
Ike Sitoresmi M Purbowati ${ }^{1}$, Sujiman ${ }^{1}$, Ali Maksum ${ }^{1}$ \\ ${ }^{1}$ Food Processing Laboratory, Agriculture Faculty, General Soedirman University, Dr. \\ Suparno street, Karangwangkal, Purwokerto 53123, Indonesia \\ Email: ikesitoresmi@yahoo.co.id
}

\begin{abstract}
The focus of this study was to evaluate the effect of different drying methods and drying level on the bioactive compounds of roselle (Hibiscus sabdariffa L.)as antioxidant agent. The experiment has been conducted in cabinet dryer and by a direct exposure on sun light as weel as by using a green house effect panel with duration of driying: 1, 3, 5, 7 hours. The observed parameters were Colour, levels of anthocyanins, vitamin $C$, and free radical trapping capacity (DPPH). The data obtained were analyzed using analysis of variance (ANOVA) and further test DMRT (Duncant Multiple Range Test). The best results from these study was the cabinet drying with 7 h of drying time which have value for color $\left(L, a^{*}, b^{*}\right)$, total anthocyanins, vitamin $C$, and antioxidant activity in respective order were $21.633 ; 6.80 ; 4.53 ; 3.22 \mathrm{mg} / 100 \mathrm{~g} ; 1238.29 \mathrm{mg} / 100 \mathrm{~g} ; 74,63 \%$.
\end{abstract}

Keyword antioxidant, roselle, anthocyanins, vitamin C

\section{INTRODUCTION}

Natural substances are generally prefered over chemical ones and generally seen healthy. As the increasing of food industri was caused the increasing of natural food additives demand like food colorant, antioxidant and preservatives. Roselle has beeing the focus of many studies and a lot has been discovered, such as its nutritional content (Shahid and Hussain, 2012; Ajayi et al., 2013), relief diabetic (Erukainure et al.,2015), lipid lowering (Wang et al., 2011), food colouring (Arueya and Akomolafe, 2014: Abdel-moemin, 2016), tofu's coagulant (Fasoyiro, 2014), antioxidant (Kharismawati et al., 2015), flavouring (Ruangsri et al., 2008). Furthermore, roselle has been documented to the antimicrobial capabilities (Purbowati et al., 2015, 2016).

Roselle (Hibiscus sabdariffa L.) is one of the Indonesian indigenous plants including herbaceous plants. Petals are bright red can be dried into dried rosella known by the public as red tea. The red color of roselle caused by it contains anthocyanin pigments that can act as antioxidants. Roselle calyx is containing of: flavonoid, gossypetin, sabdaretin, hisbicetin and anthocyanin (Azza et.al, 2011; Chumsri et.al, 2008). Purbowati et al. (2015) stated that roselle calyxes are containing a lot of phenolic compounds, anthocyanin and vitamin C. Dried roselle calyx contains, in respective order : 23.77 $\pm 0.25 ; 14.80 \pm 0.08 ; 10.74 \pm 0.14$ $\mathrm{mg} / 100 \mathrm{~g}$.

Wet roselle is a highly perishable material subject because it contains $90.42 \%$ of water (Chumsri et al., 2008). Therefore, dehydration process is the important step to extend shellife of raw material and keeping its native properties before utilization for different purposes. The primary objective of drying is the removal of water from foods, which microorganisms require for growth, 
resulting in a more shelf stable, smaller and lighter food. Reduction in moisture discourages growth of spoilage or pathogenic microorganisms (Boyer and Huff, 2008).

One of the major set back for roselle was in dried roselle form, the antioxidant activity lower than the fresh one in the same dried weight most probably due to drying method employed. Chumsri et al. (2008) stated that EC50 from the fresh roselle was $39.37 \mathrm{mg} / \mathrm{ml}$ lower than the dried ones $47.53 \mathrm{mg} / \mathrm{mL}$. This condition caused by anthocyanin as a bioactive compound from roselle will detariote under exposed by heat and light (Laleh et al.,2006; Rahmawati (2011):)

There are several methods of drying including sun or solar, conventional, and cabinet drying. There are different forms of solar drying, namely: traditional, solar box and sun oven. Traditional sun drying is low/no cost and crops are exposed to the environment. It is the preferred choice of drying for farmers in developing countries because of finance. This method of drying however is worth with many challenges including unpredictable weather, infestation of insects, pests and microbial contamination (Ekechucwu, 2010), and it poses a food safety problem for consumers.

Solar box is a box fabricated with wood and glass cover of varying sizes while sun oven is a box with reflective panels. Food is placed in a pan painted black in the box. Both solar box and sun oven are left outside to absorb energy from the sun and are safer alternatives to the traditional concrete floor, open air drying and more beneficial. Although solar box and sun oven drying are equally affected by weather as the traditional drying, they are not plagued by pests' problems. Conventional drying uses electricity and is the most practical and reliable. However, due to high cost and epileptic supply of electricity low scale farmers in developing countries cannot afford this method of food drying.

The selection of the dehydration method depends on raw material properties, the desired characteristics of the dried product, the restriction on the operating conditions and costs.

These research objective were to determine the effect of various drying method and time on anthocyanin and vitamin $\mathrm{C}$ isolation and antioxidant activity of dried roselle..

\section{METHOD}

\section{Material}

Red roselle flower (Hibiscus sabdariffa) originating from BKPH Muria Pati Ayam KPH Pati Central Java area. Chemicals needed were: reagents Folin Ciocalteu, Na2CO3, gallic acid, nutrient agar (NA), nutrient broth (NB), paper discs, Whatman papers, aquades and other chemicals for analysis.

\section{Tools}

The equipment used in this study includes cabinet dryer, greenhouse chamber effect, microwave electrolux, vacuum evaporator, burette, shaker, micro pipette, multiwell plates, spectrophotometer, analytical scales. Also needed glassware for analysis such as test tube, erlenmeyer, measuring cups and measuring flask.

\section{Decreased moisture of roselle petals}

The roselle calyxes were old, whole and clean separated from damaged or rotten calyxes and dispose of any defects in the calyxes. The calyxes are separated from the seeds and then wash with clean water and drain the water. After that, drying is done using the cabinet dryer method, Greenhouse Effect and solar dryer each with drying time 1,3,5,7 hours. Then the resulting roselle petals wrapped in a tight plastic to avoid the effects of moisture. 


\section{Extraction}

Ten gram of the dried roselle calyxes with various drying method and time were ground for 1 minute using grinder and sieved in 60 mesh. The extraction were done in $100 \mathrm{ml}$ aquadest, microwave power extraction $250 \mathrm{~W}$ and 5 minutes time of extraction for each unit combinations. Microwave used for extraction was Electrolux EMM 2007X. The slurry was radiated in microwave oven at regular intervals (one minute radiation and two minute off) to keep the temperature not rise above the boiling point (Purbowati et al., 2016). Roselle extract was filtered and concentrated with vacuum evaporator at $70 \mathrm{oC}, 44 \mathrm{cmHg}$ and blowing with $\mathrm{N} 2$ to ensure the solvent totally evaporate.

Color measurement (Tanska et al., 2005)

The result were expressed in CIEL*a*b*L color space, where $\mathrm{L}^{*}$ is the lightness, $a^{*}$ is the greenness-redness and $\mathrm{b}^{*}$ is the blueness-yellowness. The $\mathrm{L}^{*}$ component was in range of $0-100 \%$ while $\mathrm{a}^{*}$ and $\mathrm{b}^{*}$ component were in the range from -120 to +120 . Before analysis, the calibration to standard white respective plate was done.

\section{Antosianin (Fuleki et al., 1968)}

A total of $1 \mathrm{~mL}$ sample was added with $1 \mathrm{~mL}$ of acidic ethanol $(95 \%$ ethanol $+1.5 \mathrm{~N} \mathrm{HCl}(85: 15 \mathrm{v} / \mathrm{v}))$ Stored overnight at $40{ }^{\circ} \mathrm{C}$. Then diluted to $10 \mathrm{~mL}$ and centrifuged 5 minutes $1000 \mathrm{rpm}$. Measured absorbance at $535 \mathrm{~nm}$.

\section{Antioxidant capacity}

Capacity antioxidant test using DPPH method (Blois, 1985). $100 \mathrm{~mL}$ of sample add with $3 \mathrm{~mL}$ of methanol. This solution was adding with $1 \mathrm{~mL}$ of DPPH and keep in the dark for 15 minutes in room temperature. The decreasing of DPPH absorbance spectrophotometer using $\lambda 517 \mathrm{~nm}$. As standard was used gallic acid.

\section{Data Analysis}

The determination of chosen drying method and time statiscally using Statistical Product and Service Solutions (SPSS) software through Independent TTest.

\section{RESULT AND DISCUSSION Color Measurement}

The color of roselle extract from the various drying methods and times were measured using digital image anlysis according to the methods describe by Tanska et al. (2005). Result of color measurement of the extract expressed by $L^{*}, a^{*}$ and $b^{*}$. All extract were not light ( $\mathrm{L}^{*}$ value average $26.67-21.33$ ) and had a red-yellow ( positive $\mathrm{a}^{*}$ and positive $\left.b^{*}\right)$. The statistic showed there were significant differences in extract color obtained by different both drying method and drying time.

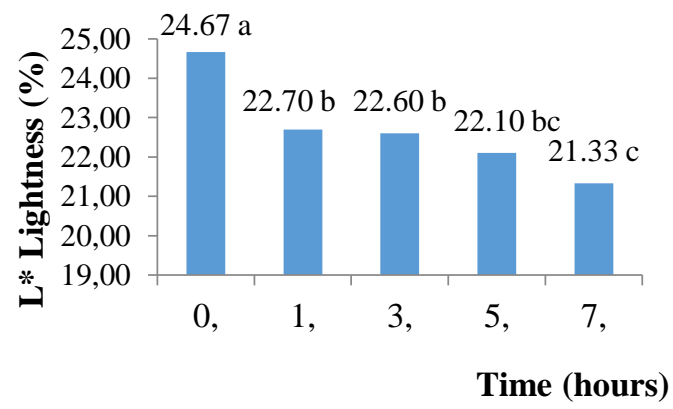

Figure 1 The influenced of drying time to the lightness $\left(\mathrm{L}^{*}\right)$ of roselle extract

According to Ogrodowska et al. (2017), the longer drying time was caused higher temperature leads to lightening. But, it showed in Figure 1, that the increasing of drying time until $7 \mathrm{~h}$, make the extract darker. This occur as a consequence of the presence of phenolic substance esspesialy anthocyanin which responsible for red color in roselle extract. According to Kharisma et al (2015), the increasing of anthocyanin content 
increased the redness level of the extract. Hosain et al.(2010) showed significant higher content of phenolic substance and antioxidant capacity of the air dried lamiacea herbs versus the fresh ones. It mean that during drying process, bioactive compounds were concentrated in plant cell.

The same reasons used for $\mathrm{a}^{*}$ and $\mathrm{b}^{*}$. Figure 2 showed that the value of $a^{*}$ is increasing with the increasing of drying time. In the other side, higher value of anthocyanin has a negative correlation with $b^{*}$
Furthermore, it was noted that the higher temperature tends to lighter (Figure 3 ). It is as a result of the absence of anthocyanin caused the $b^{*}$ value higher . Drying method made siqnificantly difference to the $a^{*}$ and $b^{*}$ value (Figure 4). Cabinet drying had no difference effect with sun drying method on $b^{*}$ value, although the value of that resulted from cabinet drying (8.55) was higher than that of sun drying method (6.99). In the other side, value of $a$, for cabinet drying, sun drying and ERK method were, in respectively order, 5.75; 5.26; 4.69.

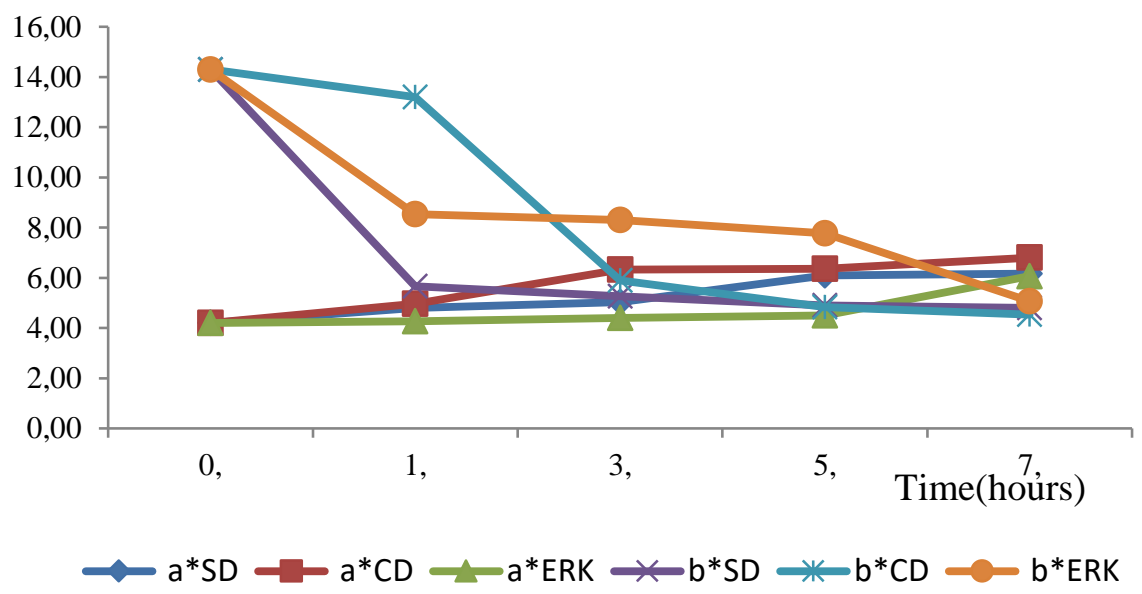

Figure 2 the influenced of drying time to the $a^{*}$ and $b^{*}$ color

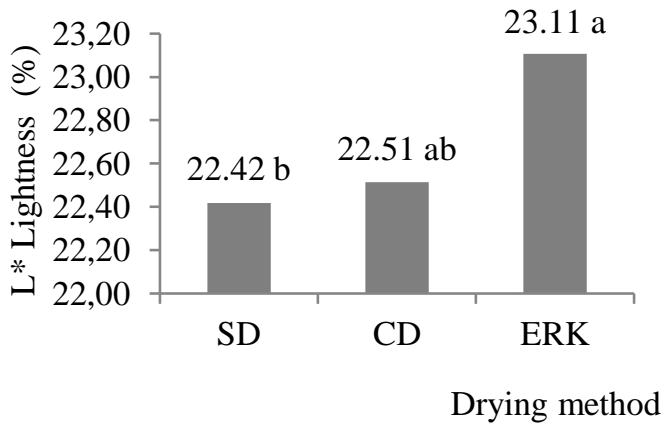

Figure 3 The influence of drying method on the lightness of roselle extract

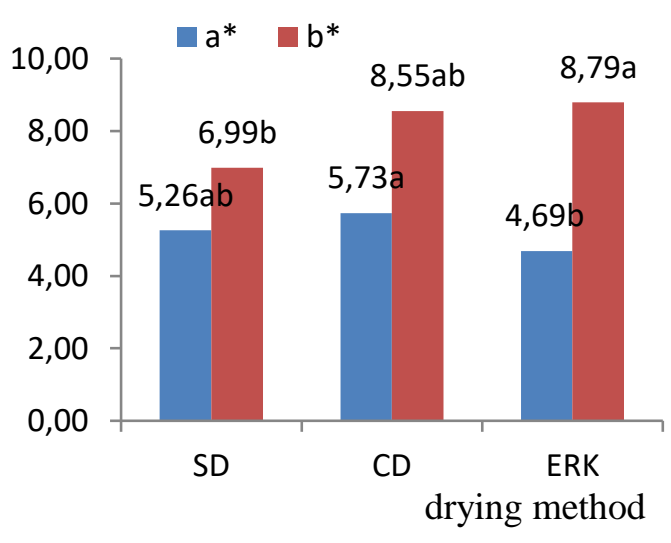

Figure 4 the influenced of drying method to the $\mathrm{a}^{*}$ and $\mathrm{b}^{*}$ 


\section{Anthocyanin}

This research showed that the increasing of drying time untill 7 hours will cause the increasing of anthocyanin content in the extract. Figure 5 showed that for 7 hours drying time, anthocyanin content in roselle extract was $2.86 \mathrm{mg} / 100$ g. The increasing for time drying made the increasing of anthocyanin content.

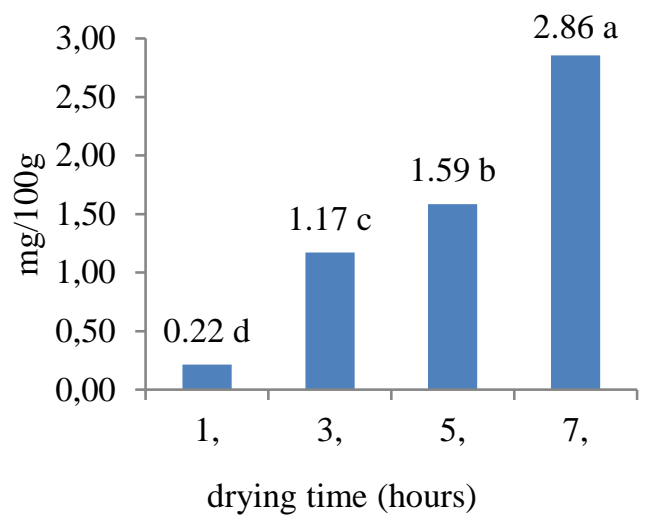

Figure 5 the influence of drying time on the antocyanin content of roselle extract

Figure 6 shows that, although the position of the cabinet drier line above sun drier, the slope or rate of increase of anthocyanin levels in the extract using cabinet drier is 0.46 lower compared with the sun drier 0.48 . However, up to 5 hours of drying, anthocyanin levels in the extracts using the cabinet drier higher than the sun drying.

This condition caused by the cabinet drying used a temperature of $50^{\circ} \mathrm{C}$ and is relatively constant. As for sun drying method, the average temperature measured was $40^{\circ} \mathrm{C}$ and fluctuated depended the climate and season at the time of drying. According to Husni et al. (2014) water content of padina sp which treated by sun light exposure can not evaporate constanly caused by the drying temperature using this method was fluctuated. As a result the water content in the material was decreased faster using the cabinet until the 5th hour of drying time. But finally at 7 hours of drying, the amount of anthocyanin in the extract using cabinet dryer $(3.42 \mathrm{mg} / 100 \mathrm{~g})$ was lower than the extract produced from dried roselle using a sun drying method (3.74 $\mathrm{mg} / 100 \mathrm{~g}$ )

According to Santosa and Dewi (2009) drying process could release fenolic acids bonds from cell tissue and then bioactive compounds was extracted out. Sari et al. (2012) stated that the optimum dirying temperature to get maximum fenolic substances was $60^{\circ} \mathrm{C}$. Drying method with used temperature more than $60^{\circ} \mathrm{C}$, after 4 minutes will degrade the amount of fenolic substances.

According to Purbowati et al. (2016), that the stability of anthocyanin is affected by temperature. The higher the temperature the greater the likelihood of anthocyanin degradation. The damage will increase with the heating temperature.

The amount of anthocyanin of roselle extract produced from the cabinet dying method $(2.08 \mathrm{mg} / 100 \mathrm{~g})$ was the highest one compare with sun drying method $(1.57 \mathrm{mg} / 100 \mathrm{~g})$ and ERK (0.72 $\mathrm{mg} / 100 \mathrm{~g})$.

\section{Vitamin C}

Vitamin C is a type of water soluble vitamin. Reduction in the amount of water in the cells significantly affect the vitamin $\mathrm{C}$ content produced. Figure 8 showed Vitamin $\mathrm{C}$ content on different drying method. Vitamin $\mathrm{C}$ content in dried roselle calyxes, which is drying using the cabinet method $(47.721 \mathrm{mg} / 100 \mathrm{~g})$ was higher than the drying method using sunlight $(39.27 \mathrm{mg} / 100 \mathrm{~g})$ and greenhouse effect $(3.061 \mathrm{mg} / 100 \mathrm{~g})$. This is because in the drying using the cabinet, the resulting water content of roselle is lower than the water content of dried roselle water using greenhouse effect and sunlight. So for the same material weight, the water content for the dried roselle with greenhouse and 
sun effect is more than the drying of the cabinet.

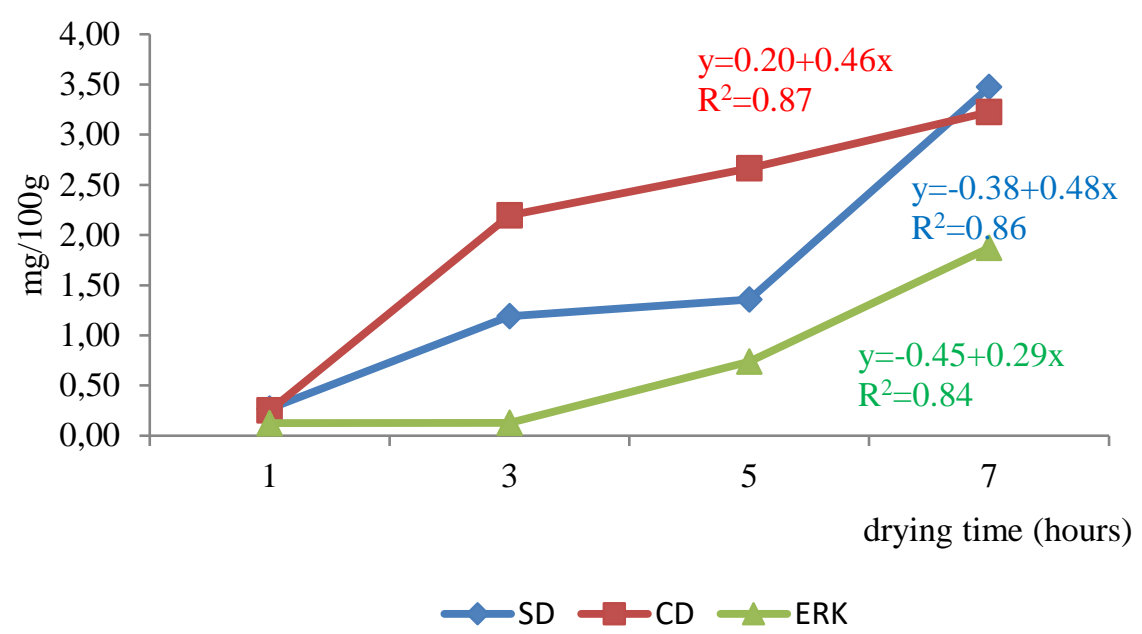

Figure 6 the influence of drying time on the anthocyianin roselle extract

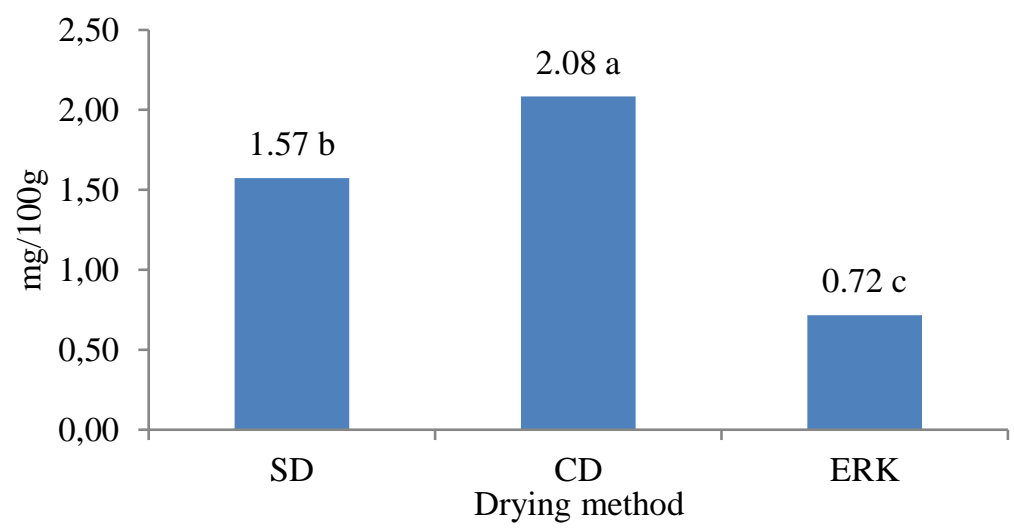

Figure 7 The influenced of drying method on the anthocyanin content of roselle extract

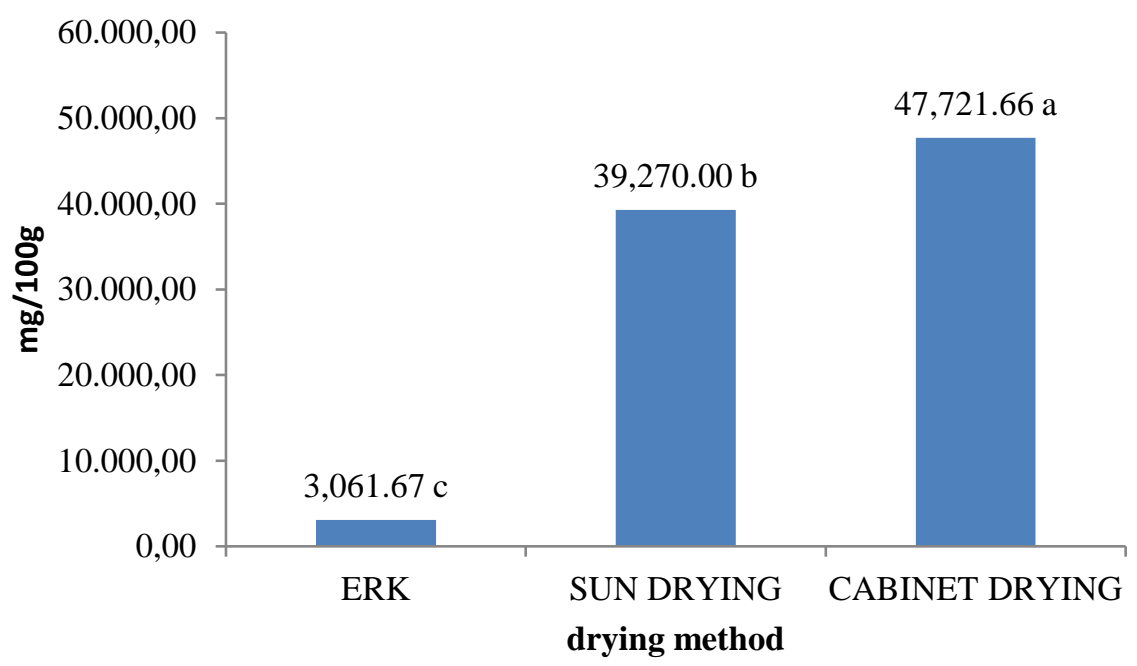

Figure 8 vitamin $\mathrm{C}$ content on different drying method 
The drying time has a significant effect on vitamin C (Figure 9). The longer the drying time of the water content in the ingredients is less. So with the same weight of water content in the roselle with a longer drying time will have less water content. This results in more vitamin $\mathrm{C}$ content. For drying time 1 and 3 hours of vitamin $\mathrm{C}$ content is relatively the same, because it is still estimated adaptation conditions.

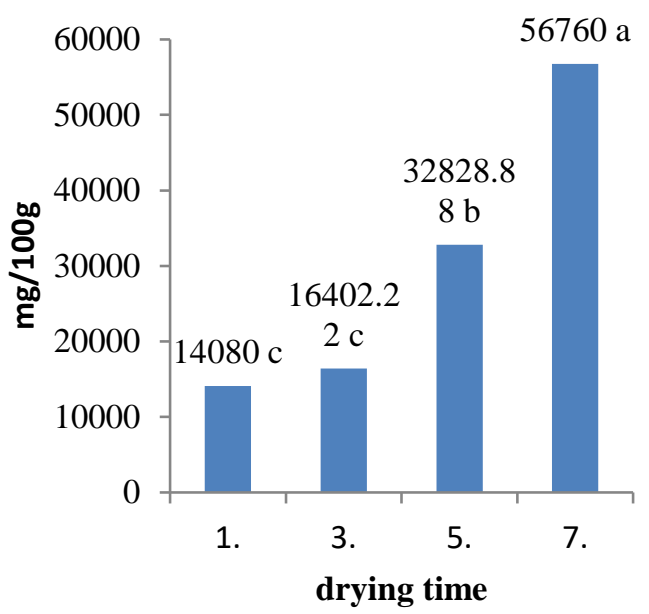

Figure 9 influence of drying time on vitamin $\mathrm{C}$ content

\section{Antioxidant activity}

Antioxidant activity is influenced by the amount and type of antioxidant compounds. In general, the more amount of antioxidant compounds, the activity of antioxidant compounds in neutralizing free radicals will be higher (Karisma et al., 2015). At each treatment, the higher the concentration of extract used, the radical inhibitory activity is also increasing (Figure 10). The highest inhibition $(74.676 \%)$ was obtained from cabinet drier for 7 hours of drying. Anova analysis showed that drying method and drying time had significant effect on antioxidant activity. The activity determined largely by its reactivity as a hydrogen donor agent, its reactivity with other antioxidants, the metal bonding transition potential and its ability to stabilize and delocalize unpaired electrons. Roselle extract has anthocyanin content as part of phenolic compound. In addition, the content of vitamin $\mathrm{C}$ in the extract was quite high $20.47 \mathrm{mg} / 100 \mathrm{~g}$. According to Tsai et al (2002) antioxidant activity of roselle extract has a strong correlation with anthocyanin content. Falade et al. (2005) states that roselle extract has a high vitamin content. Vitamin $\mathrm{C}$ is known as an antioxidant compound. This result is possible because the antioxidant activity is not only caused by phenolic content, but it can be caused by some other phytochemicals such as ascorbic acid, tocopherol and other pigments with synergistic mechanisms which also determine the activity of antioxidants.

A decrease in phenolic content does not lead systematicaly to a decrease of antioxidant activity. Indeed, with lower phenolic content, one also can have a higher antioxidant activity (Buchner et al., 2006). 


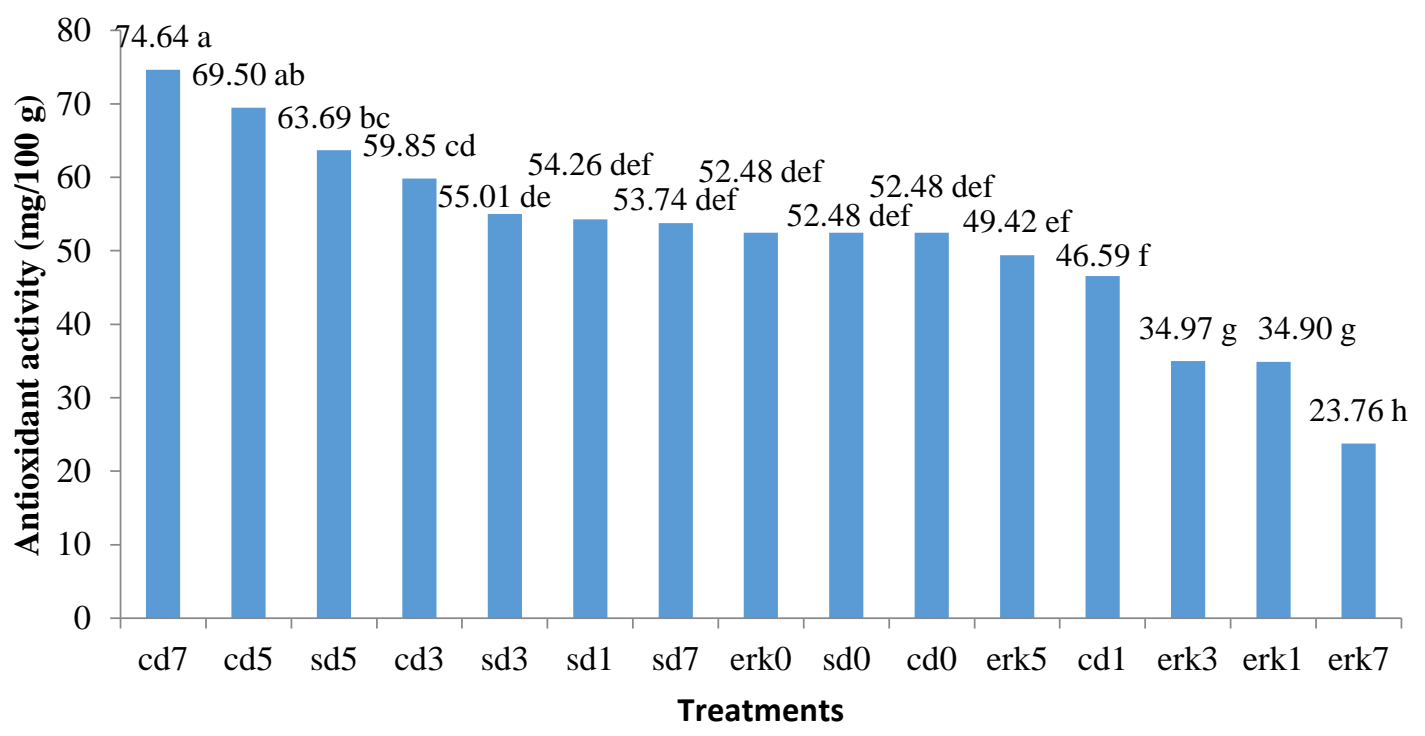

Figure 10 Antioxidant activity on different drying method and drying time

\section{CONCLUSION}

The best results from these study was the cabinet drying with $7 \mathrm{~h}$ of drying time which have value for color $\left(\mathrm{L}, \mathrm{a}^{*}, \mathrm{~b}^{*}\right)$, total anthocyanins, vitamin $\mathrm{C}$, and antioxidant activity in respective order were: $21.633 ; 6.80 ; 4.53 ; 3.22 \mathrm{mg} / 100 \mathrm{~g}$; $1238.29 \mathrm{mg} / 100 \mathrm{~g} ; 74,63 \%$.

\section{REFERENCE}

A.O.A.C. 2000. Official methods of analysis of the association of official chemists international, 17thed. The Association of Official Chemists International, Gaithersburg, USA

Abdel Moemin, AR. 2016. Effect of roselle calyces extract on the chemical and sensory properties of functional cupcakes. Food sci and Human Wellness 5:230-237

Ajayi, OA., Ola OO., dan Akinwunmi OO. 2017. Effect of drying method on nutritional composition, sensory and antimicrobial properties of Ginger (Zinginber officinale). International Food Res. J. 24(2): 614-620.

Azza A. Abou-arab, Ferial M, Abu Salem Esmat A. 2011. Physico chemical properties of natural pigment (anthocyanin) extracted from roselle calyxes. J. of American Science7(7): 445-456

Arueya GL dan Akomolafe BO. 2014. Stability studies of microencapsulated anthocyanin of roselle (hibiscus sabdariffa) in Native Starch and its potential application in jam production. J.of Envirn. Sci. 8(7):112-122.

Buchner N, A Krumbein, S Rohn and L Kroh. 2006. Effect of thermal processing on the flavonols rutin and quercetin. Rapid Communication in Mass Spectrometry 20(21):3229-3235

Chumsri P, Sirichele A, Itharat A. 2008. Studies on the optimum condition for extraction and concentration of Roselle (Hibiscus sabdariffa Linn) extract. Songklanakarin, J.Sci. Technol. 30 ( Suppl) 133-139

Doughari JH. 2006. Antimicrobial activity of Tamarindus indica Linn. Trop J Pharmac Res. 5:597-603.

Ekechukwu VO. 2010. Solar Drying Technology: An overview Paper. Presented at FUTO Alternative Energy Conference, Federal University of Technology Owerri. 
Erukainure OL, O Okafar, A Ajayi,O Obade,A Ogunji, T Okporua, Y Suberu, O Oke, A Ozumba, O Oluwole and G Elemo. 2015. Developed beverage from roselle calyx and selected fruits modulates B-cell function, improves insulin sensitivity and attenuates hyperlipidaemia in diabetic rats. Journal of basic and applied science 4: 307-313

Falade OS, Otemuyiwa IO, Oladipo A, Oyedapo OO, Akinpelu BA., Adewusi SRA. 2005. The chemical composition and membrane stability activity of some herbs used in local therapy for anemia. $\mathrm{J}$. Ethnopharmacol, 102:15-22

Fasoyiro, SB. 2014. Physical, chemical and sonsory qualities of roselle water extract coagulated tofu compared with tofu from two natural coagulants. Official Journal of Nigerian Institute of food science and technology 32(2);97-102.

Fuleki T. Francis FJ. 1968. Quantitative methods for anthocyanins, 1 . Extraction and determination of total anthocyanin in Cranberries, J. Food Sci. 33(1); 72-77

Husni A, Putra DR dan Lelana IYB. 2014. Aktivitas antioksidan Padina sp pada berbagai suhu dan lama pengeringan. JPB Perikanan 9(2):165-173.

Purbowati, ISM, Syamsu K, Warsiki E dan Rukmini HS. 2015. Evaluasi toksisitas, aktivitas antibakteri dan antioksidan komponen bioaktif rosela dengan variasi jenis pelarut. $\mathbf{J}$ Tek Ind Pert. 25(2) : 182-189.

Purbowati ISM, Syamsu K, Warsiki E dan Rukmini HS. 2016. Optimizationof phenol extraction from Roselle
(Hibiscus sabdariffa) by micrawave asissted extraction as antibacterial and antioxidant agent. $\mathrm{J}$ Tek Ind Pert 26(1): 9-22.

Ruangsri P, Chumsri P, Anschalee S dan Arunpora I. 2008. Changes in quality and bioactive properties of concentrated Roselle (Hibiscus sabdariffa Linn) extract. As J Food Ag-In. 1(02):62-67.

Santosa B dan Dewi L. 2009. Kandungan antioksidan dan fenolik total pada ekstrak rosela dan aplikasinya pada pembuatan selai. Prosiding Seminar Nasional Sans dan Pendidikan Sans. IV(3):582593.

Sari DK, Wardhani DH dan Prasetyaningrum A. 2012. Pengujian kandungan total fenol kappahycus alvarezzi dengan metode ekstraksi ultasonic dengan variasi suhu dan waktu. Jurusan teknik kimia fakultas teknik UNDIP. Prrosiding NST ke-3 tahun 2012. Fakultas teknik universitas Wahid Hasyim, Semarang.

Karismawati AS, N Nurhasanah, TD Widyaningsih. 2015. Pengaruh minuman fungsional jelly drink kulit buah naga merah dan rosella terhadap stres aksidatif. J Pangan dan Agroindustri 3(2): 407-416

Shahid, M and F Hussain. 2012. Chemical composition and mineral content of zingiber officinale and Alpinia allughas (Zingiberaceae) rhizomes. International hournal of Chemical and biochemical science 2:101-104 